We thank Miss Angela O'Gorman for her assistance. This work was supported in part by the award of a fellowship to one of us (H. F.) by the Department of Agriculture and Fisheries, Dublin.

Marx R. Stuart Hubert T. Fuller

Department of Botany, University College,

Dublin.

Received September 12; revised October 31, 1967.

${ }^{1}$ Editorial comment, Nature, 215, 141 (1967).

${ }^{2}$ Hoshina, T., and Ookubo, N., J. Tokyo Univ. of Fish., 42, 1 (1956).

3 Tiffney, W. N., Mycologia, 31, 310 (1939).

4 Vishniac, H. S., and Nigrelli, R. F., Zoologica, 42, 181 (1957).

${ }^{5}$ Scott, W. W., Developments in Industrial Microbiology, 5, 109 (1964).

- Unestam, T., Physiol. Plant, 18, 483 (1965).

7 Mulcahy, M. F., Nature, 215, 143 (1967).

Willoughby, L. G., J. Ecol., 50, 733 (1962).

${ }^{\circ}$ Coker, W. C., The Saprolegniaceae (University of North Carolina Press, 1923).

${ }^{10}$ Coker, W. C., and Matthews, V. D., North American Flora, 2, 20 (1937).

${ }^{11}$ Seymour, R. L., thesis, Virginia Polytechnic Institute (1968).

${ }^{12}$ Scott, W. W., and Warren, C. O., Tech. Bull., 171 (Virginia Agricultural Experimental Station, 1964).

13 Te Strake, D., Phyton, Intern. J. Exp. Bot., 12, 147 (1959).

\section{Prey Selection: Oddity or Conspicuousness?}

Prelowskr has shown that goshawks (Accipiter gentilis) select as prey pigeons (Columba livia) which differ in colour from most pigeons which are present in Polish forests ${ }^{1,2}$. Salt ${ }^{3}$ has shown how these and other experimental results fit rather well into the generalization that predators preferentially capture prey animals which are odd, or which differ in some way from most prev. As Pielowski noted, however, it is probably easier for a goshawk to fix its attention on the odd-appearing member of a flock, and it is possible that the goshawks were merely taking conspicuous individuals out of the flock. Selection for conspicuous prey has been amply verified by experimenta. tion $^{4-8}$. I have attempted to determine the parts played by oddity and conspicuousness in prey selection.

A tamed hawk ( $F^{\top}$ alco sparverius) preyed on laboratory mice which were either white or which had been dyed grey. In each experiment, nine mice of one colour and one of the other were presented on a table which was eoloured to match one or the other colours of mice. Each of the two colour combinations of mice was replicated fifty times on each of the two colours of background, giving a total of two hundred experiments.

Experimental series $A$ and $B$, in which the background was grey, clearly show that the hawk selected conspicuous, but not odd, prey (Table 1). In view of these results, I suggest a reconsideration of the generalization that odd prey is preforontially selected by predators. In series $C$ and $D$, where grey mice were conspicuous, prey selection did not differ from random. I suggest that this is a result of a conflict in preference for $(a)$ white and $(b)$ conspicuous. ness. The hawk took a significantly longer time ( $t$ test, 95 per cont lovel) to select a mouse in series $C$ and $D$ than it did in sories $A$ and $B$ (Table 1), which can be considered as evidence for conflict. I cannot explain this unexpected preference for white mice other than by suggesting that the hawk may have becomo accustomed to preying on white

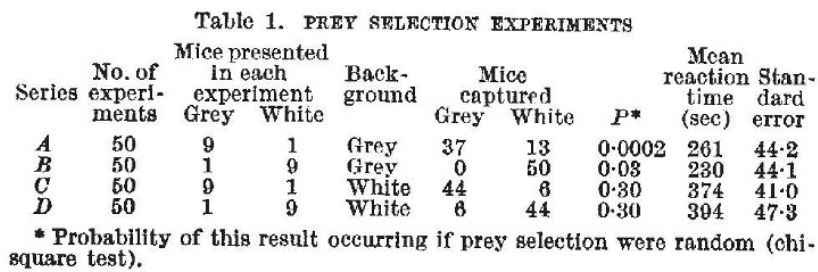

mice in series $A$ and $B$. The hawk may thus have formed a "specific searching image" in series $A$ and $B$ and maintained it throughout series $C$ and $D$. Further experiments are in progress.

Department of Zoology,

University of North Carolina,

Chapel Hill, North Carolina.

Received October 12; revised December 5, 1967.

' Pielowski, Z., Bull. Acad. Pol. Sci. Ser. Sci. Biol., 7, 401 (1959)

${ }^{2}$ Pielowski, Z., Ekologia Polska (A), Tom IX, No. 11 (1961).

${ }^{2}$ Salt, G. W Eeol. Monog, 37, 113 (1967).

‘ Sumner, F. B., Proc. US Nat, Acad. Sci.,20, 559 (1934).

${ }^{5}$ Sumner, F. B., Proc. US Nat. Acad. Sci, 21, 345 (1935).

' Sumner, F. B., Amer. Nat., 69, 245 (1935).

'Isely, F'. B., Ecology, 19, 370 (1938).

- Dice, L. Rontrib, Lab. Vert. Biol. Dniv. Mich., Ann Arbor, No. 34 (1947). - Tinbergen, L., Arch. Neer. Zool., 13, 265 (1960).

\section{Pigmentation in the Radial Nerve of Diadema antillarum}

Recent examination by phase-contrast microscopy of teased, fresh or macerated radial nerve, or of frozen sections in Diadema antillarum, has shown the presence of reddish cells that are neither amoebocytes nor chromatophores, but which resemble neurones in their general form (Figs. 1 and 2).

The presence of a reddish pigment in the radial nerves of this echinoid is of special interest because in experimental conditions the nerve can serve as a photoreceptor in the characteristic shadow response ${ }^{1-2}$. Photosensitivity is maximal between 455 and $460 \mathrm{~m} \mu$ (ref. 3), and the pigment, when extracted in acidified diethyl ether, absorbs maximally in the visible range at $465 \mathrm{m \mu}$. Absorption of both visible and ultraviolet radiation corresponds closely with that of the reddish pigment which can be extracted from the skin ${ }^{4}$ and which is now known to be echinochrome $A$. The near coincidence of these maxima coupled with the presence of the pigment in the photosensitive skin as well as in the radial nerve has caused speculation that the pigment may be involved in photoreception ${ }^{5,6}$. Our recent discovery in the radial nerve of similarly pigmented cells which resemble neurones therefore reinforces the idea.

Caution has already been urged, however ${ }^{7}$. Most of the red pigment in the radial nerve is in the ubiquitous amoebocytes or in their disorganized remains, and the pigmented presumptive neurones are rare. On the other hand, photoreceptors for the shadow response seem to be widespread in the nerve and it is unlikely that amoebocytes are directly involved. Again, previous determinations of spectral absorption have relied entirely on extracted

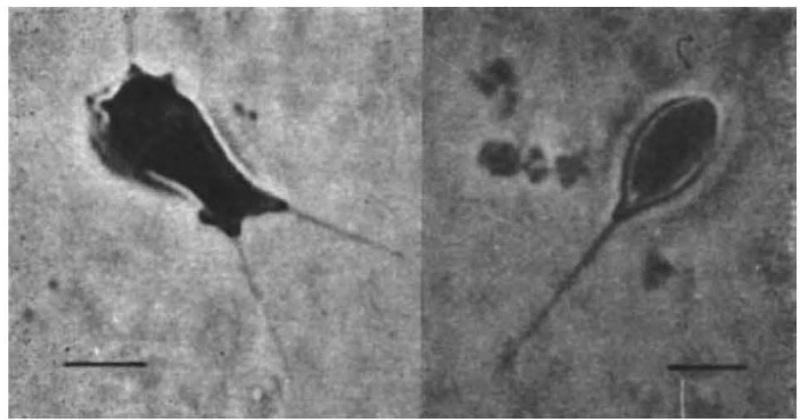

Fig. 1

Fig. 2

Figs. 1 and 2. Two of the pigmented structures whlch have been interpreted as neurones in the living radial nerve of Diadema, which wer examined by microspectrophotometer. Scales: Fig. 1, 5.3 $\mathrm{m} \mu$; 